\title{
Efficiency and profitability in pork production
}

\author{
OLLI RANTALA \\ Department of Agricultural Economics, University of Helsinki, \\ SF-00710 HELSINKI 71
}

\begin{abstract}
Under prevailing production restrictions the profitability of agricultural production increasingly depends not only on prices of products and inputs, but on how effectively and economically the existing capacity and animal breeds are utilized on farms. The technical efficiency of pork production in Finland is generally high. The average feed conversion rate on farms is only about $16 \%$ lower and daily liveweight gain $20 \%$ less than results from experimental stations. Variation between farms is, however, considerable. The means of technical results between the best and poorest farms differ by $20-30 \%$. Results also tend to deteriorate and relative deviations increase, especially in large piggeries.

The average gross margin percentage was $12 \%$. Variation in the gross margin per pig was wider between farms than between years. The feed conversion efficiency proved to be the most significant factor contributing to profitability in pork production. Variation in the feed conversion rate accounted for $30 \%$ of total variation in the gross margin. Cost variation was one third larger than the variation of total receipts per pig. The cost of feed varied twice as much as piglet cost.

Since the genetic quality of animals in a given region is rather even, variations in productivity depend upon internal factors of piggeries. The large variation in efficiency and profitability over farms emphasizes the human factor i.e. the role of the farmer as the most important factor contributing to successful production.
\end{abstract}

Index words: pork production, efficiency, profitability

\section{Introduction}

During the last two decades, there has been a strong structural change in pork production. The most conspicuous features have been the growth of production and size of enterprises, and the increasing degree of specialization. The production of piglets and pork has be- come channelled into different farms. About two-thirds of piggeries are specialized in only one enterprise and $73 \%$ of pigs for slaughter are now raised from piglets transported from other farms. The application of technical and organizational improvements has been economically well motivated at the farm level due to the relatively good profitability of produc- 
tion (Anon. 1984). As well as structural changes, as the increased utilization of purchased inputs and improvements in feed quality have also enhanced productivity. The higher productivity of genetically improved animals can have been utilized in practical farming.

Agricultural production is characterized by output variations, even with a constant supply of inputs. Variations depend upon fixed and variable production factors, and finally upon random or risk factors. However, it is difficult to assign contributions to the variation, as the proportion and effects of different inputs cannot be precisely measured and the effects of fixed factors on the productivity of variable factors tend to differ from farm to farm.

Production disturbances may arise through the combined influence of the genetic quality of animals, management and other production factors. GöranSSON (1977) has estimated producers' losses of upto $10-20 \%$ of the gross return in pork production. In practice, these losses become apparent in slow growth, poor feed utilization and a high death rate.

\section{Material}

The efficiency of pork production and its variation were examined on the basis of piggery records from 49 farms. These farms have specialized in pork production and they belong to cooperative slaughteries for the regions of Sata-Häme (SOT) and Lounais-Suomi Cooperative Slaughtery (LSO). SOT's records are from 1975-1977 (RANTALA 1980) and LSO's from 1977-1983 (VÄLIMÄKı 1985). All the farms use piglets raised on other farms, and the fattening process is organized as a batch system. SOT's records cover 28 and LSO's 21 piggeries (Table 1.)

In the SOT region the piggeries accommodated on average of 366 , and in the LSO region 309 slaughter pigs. Though the piggeries are large by Finnish standards, all of them are typical family farms. They can also be consi- dered as rather rationally managed farms. In the SOT region the farms were grouped into two classes on the basis of size of the piggery. The limit was 400 pig places. The results were also examined in classes grouped on the basis of the main type of feed. Most of LSO's piggeries have less than 300 pig places and they use purchased feed mixture. LSO's farms were grouped into two classes on the basis of feeding method: farms which used trough feeding and those which used floor feeding.

Input-output relationships, technical efficiency and some financial results and their variation were examined on the basis of farm records and data collected in the slaughteries. Economy of production was measured by gross margins computed by batches. Variable production costs were divided into feed, piglet and miscellaneous variable costs. Miscellaneous costs consist of veterinary, electric, heating and cleaning costs together with the interest on animal and working capital. Gross margin represents the returns to fixed costs i.e. buildings and equipments used in pork production, and also to family labour.

Over a short period, existing fixed costs in an enterprise are constant. For these costs to be offset, the fixed factors of production should be utilized as effectively as possible. With fixed factors constant, the greater the

Table 1. Number of piggeries, batches and slaughtered pigs.

\begin{tabular}{lcccr}
\hline $\begin{array}{l}\text { Region/ } \\
\text { Year }\end{array}$ & Piggeries & $\begin{array}{c}\text { Batches } \\
\text { Average } \\
\text { size }\end{array}$ & $\begin{array}{c}\text { Number } \\
\text { of pigs }\end{array}$ \\
\hline $\begin{array}{l}\text { SOT region } \\
1975\end{array}$ & 16 & 34 & 366 & 12229 \\
1976 & 22 & 51 & 367 & 19109 \\
1977 & 27 & 57 & 365 & 20274 \\
Total & 28 & 142 & 366 & 52612 \\
LSO region & & & & \\
1977 & 3 & 10 & 415 & 4615 \\
1978 & 7 & 20 & 394 & 8457 \\
1979 & 6 & 17 & 408 & 7069 \\
1980 & 5 & 15 & 355 & 5388 \\
1981 & 9 & 21 & 394 & 8352 \\
1982 & 16 & 38 & 316 & 11747 \\
1983 & 16 & 22 & 297 & 9082 \\
Total & 21 & 153 & 309 & 54710 \\
\hline
\end{tabular}


gross margin the more profitable is the production.

Financial results were calculated for those batches in which the data could be adjusted to enable calculation on a consistent basis. In the SOT region there were 18 such farms with a total of 96 batches and in the LSO region 19 farms with 120 batches. The gross margin was calculated per pig and per pig place. The gross margin percentage was also calculated, i.e. the gross margin expressed as a percentage of the gross return.

\section{Results}

\section{Technical efficiency}

The efficiency of pork production is usually measured by the feed conversion rate i.e. the quantity of feed (f.u.) consumed per unit of liveweight gain. As well as the genetic quality of the animals, the production environment and feeding regime affect the feed conversion efficiency, too. In the SOT region the average feed conversion rate was 3.35 f.u. $/ \mathrm{kg}$ over the weight range from $24.4 \mathrm{~kg}$ of live weight to $70.4 \mathrm{~kg}$ of carcasss weight (Table 2). Two-thirds of the farms attained a result between 3.18 and $3.46 \mathrm{f}$.u. $/ \mathrm{kg}$. In piggeries with less than 400 pig places, the feed conversion rate was $0.15 \mathrm{f} . \mathrm{u} . / \mathrm{kg}$ better than in larger piggeries. This difference is statistically significant $(\mathrm{P}<0.05)$. There was no difference between farms which used a commercial feed mixture and farms which used homeproduced grain and purchased protein concentrate.
In the LSO region, the average feed conversion rate was $3.11 \mathrm{f} . \mathrm{u} . / \mathrm{kg}$ over the weight range from $25.4 \mathrm{~kg}$ to $72.4 \mathrm{~kg}$. With trough feeding the feed conversion rate was 0.15 f.u. $/ \mathrm{kg}$ better $(\mathrm{P}<0.05)$ than with floor feeding.

The average daily liveweight gain of batches in the SOT region was $616 \mathrm{~g}$, and two-thirds of the farms attained a result between 590 and $643 \mathrm{~g}$. In the LSO region, the daily growth was $714 \mathrm{~g}$. With trough feeding the growth was 26 $\mathrm{g}$ higher $(\mathrm{P}<0.05)$ than with floor feeding. The daily liveweight gain is an index of the average utilization of growth capacity of the pigs in each piggery. The rate of growth influences the length of the feeding period, since a higher throughput of fast growing pigs can be achieved per place and thus the fixed production capacity will be utilized more efficiently.

The average number of feeding days in the SOT region was 124 days, and two-thirds of the farms attained a result between 118 and 129 days. The rotation time, which is calculated by adding to the feeding period the time spent on filling, empting and cleaning the piggery, was 137 days, and two-thirds of the farms attained a result between 128 and 146 days. Thus on average 2.7 batches were raised per year. Only in piggeries with more than 500 pig places did the yearly number of batches significantly decrease. In the LSO region, the feeding period and rotation time were about two weeks shorter than in the SOT region.

The average death rate in the SOT piggeries was $1.7 \%$ of the number of purchased piglets and the rate clearly increased in large

Table 2. Technical efficiency and variation.

\begin{tabular}{|c|c|c|c|c|c|c|}
\hline & \multicolumn{3}{|c|}{ SOT region } & \multicolumn{3}{|c|}{ LSO region } \\
\hline & Mean & sd & Range & Mean & sd & Range \\
\hline Feed conversion rate, f.u. $/ \mathrm{kg}$ & 3.35 & $(0.16)$ & $3.06-3.83$ & 3.11 & $(0.20)$ & $2.40-3.72$ \\
\hline Daily liveweight gain, $\mathrm{g}$ & 616 & (29) & $674-553$ & 714 & $(60)$ & $872-567$ \\
\hline Feeding days & 124 & ( 6 ) & $116-139$ & 109 & ( 8 ) & $84-130$ \\
\hline Rotation time, days & 137 & (11) & $123-165$ & 121 & ( 9 ) & $97-143$ \\
\hline Batches per annum & 2.7 & - & $3.0-2.2$ & 3.0 & $(0.2)$ & $3.6-2.6$ \\
\hline Output, kg/pigplace./a & 187 & (14) & $206-157$ & 223 & (27) & $299-67$ \\
\hline Death rate, $\%$ & 1.7 & (0.7) & $0.2-3.0$ & 1.2 & (1.1) & $0-5.3$ \\
\hline
\end{tabular}


REL

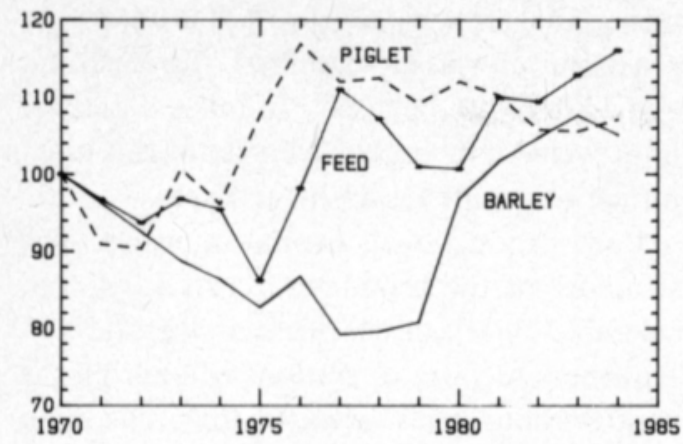

Fig. 1. Price changes of barley, piglet and commercial feed mixture in relation to the producer price of pork.

variable production costs $6.3 \%$ and of the margin $42.7 \%$. The variation in feed costs was twice as large as the variation in piglet cost.

The gross margin was negative in $3 \%$ of all batches i.e. receipts did not even cover all the variable costs. More than half of the farms had batches in which the margin percentage was below $5.0 \%$. On farms with more than 400 pig places every other batch had a margin percentage below $5.0 \%$. In the LSO region, within year variations of margin between farms were also considerably greater than variation between years. The average variation in margin between farms was $28 \%$. On the best farms the margin was more than three times greater than on the poorest ones.

Table 5. Gross margin in pork production in the SOT's region in 1975-1977.

\begin{tabular}{|c|c|c|c|c|}
\hline \multirow[t]{2}{*}{ Group } & \multicolumn{2}{|c|}{ Gross margin } & \multirow{2}{*}{$\begin{array}{c}\text { Gross } \\
\text { margin } \\
\%\end{array}$} & \multirow[t]{2}{*}{ Range } \\
\hline & Fmk/pig & Range & & \\
\hline I & 83 & $54-115$ & 14.1 & $9.8-19.4$ \\
\hline II & 48 & $25-87$ & 8.2 & $4.3-14.5$ \\
\hline VT & 91 & $65-115$ & 15.4 & $11.4-19.4$ \\
\hline TR & 44 & $26-74$ & 7.6 & $4.3-12.1$ \\
\hline
\end{tabular}

Size of the piggery

$I=<400$ pigs

$\mathrm{II}=>400$ pigs

Type of the feed

$\mathrm{VT}=\mathrm{Grain}+$ purchased protein concentrate

$\mathrm{TR}=$ Commercial feed mixture
FMK/PIG

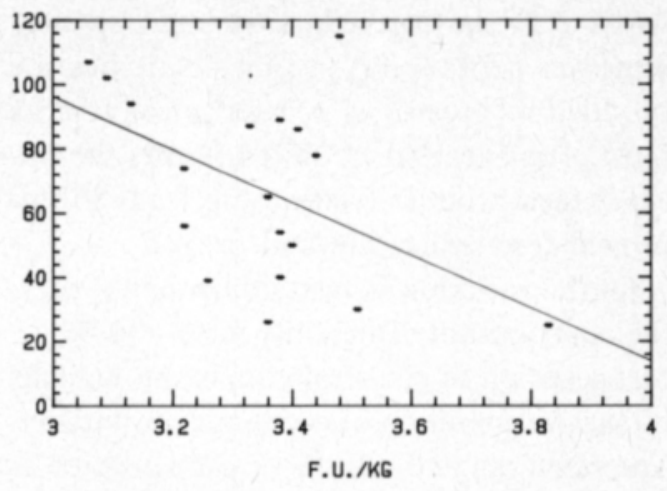

Fig. 2. Correlation between gross margin per pig and feed conversion rate.

\section{Conclusions}

On average pig farms are managed quite efficiently. The difference in feed conversion rate between practical and experimental rearing is $0.4-0.5 \mathrm{f} . \mathrm{u} . / \mathrm{kg}$ and the difference in daily liveweight gain $140-210 \mathrm{~g}$. The feed conversion efficiency is thus $16 \%$ poorer and daily growth $20 \%$ lower in practical farming than in optimal experimental environments. The variation between farms is considerable. In extreme cases means differ over a range of $20-30 \%$. Results also tend to deteriorate and their variation widens in larger piggeries. As the genetic quality of animals is rather even within a limited region, the production environment and feeding are of great importance. Particularly in large piggeries, well regulated feeding and an adapted environment are undispensable conditions for the economic utilization of commercial feed mixtures.

The lower the feed input per unit of liveweight gain, the more efficient is the technical feed conversion. The feed conversion rate does not necessarily indicate the most economic intensity of feeding, as the latter also depends on the length of the feeding period, sale weight and whether the production is intermittent or continuous. The economic optimum is based on marginal criteria while the feed conversion rate on average criteria assuming, that the lowest point of the average 
feed cost curve is also economically optimal. An increase in the feed conversion rate also improves profitability, as in most cases the production process is not technically at its most efficient level. A shift towards the optimal feed-product relationship leads to improved feed utilization and profit.

Of the variation in feed utilization of pigs, the contribution of heredity is $30-40 \%$, so that selection of genetically superious animals is decisive condition of economic production. The remaining $60-70 \%$ of the variation is mainly attributable to feeding and environment. These factors are under the farmers control. The large variation in efficiency over farms emphasizes the ability and experience of the farmer as the most important factor contributing to successfull production.

In raising pigs to a carcass weight of $72 \mathrm{~kg}$, an improvement of 0.1 f.u. $/ \mathrm{kg}$ in the feed conversion rate leads to a $7.5 \mathrm{~kg}$ reduction in feed consumption during the fattening period. If the price of feed is $2.13 \mathrm{Fmk} / \mathrm{kg}$, the feed cost will decrease by $16 \mathrm{Fmk}$ per pig. This means that in a piggery with 300 places the gross margin will increase by $17 \mathrm{Fmk}$ per pig and $15300 \mathrm{Fmk}$ per year. In many cases, an improvement in feed conversion of this magnitude can quite easily be achieved.

Pork production is capital intensive. The structure of the production costs is of considerable significance if one examines the consequences to farm operations of altering the contributions of different factors. The main part of the cost of pork production consists of feed and piglet cost, whose additional proportion of production cost is $85-88 \%$. Feed may partly or completely consist of a commercial feed mixture, so that purchased supplies constitute the main part of production costs. On the other hand, returns to the farmers own labour and capital per unit of output is small, thus the range within which prices and inputoutput relationships can vary without jeopardizing profitability is extremely small.

result variation on some family farms. M.A. thesis, Dep. of Agr. Econ. University of Helsinki. 65 p.

VĀLIMĀKı, K. 1985. Efficiency and profit variation in pork and piglet production. M.A. thesis, Dep. of Agr. Econ. University of Helsinki. 73 p.

Ms received November 7, 1985

\title{
SELOSTUS
}

\section{Tuotannon tehokkuus ja kannattavuus sianlihantuotannossa}

\section{Olli Rantala}

\begin{abstract}
Maatalousekonomian laitos, Helsingin Yliopisto, 00710 Helsinki
\end{abstract}

Tuotantorajoitusten ollessa voimassa tuotannon kannattavuus riippuu yhă enemmän paitsi tuotteiden ja tuotantopanosten hinnoista myös siită, miten tehokkaasti ja

taloudellisesti olemassa olevaa kapasiteettia ja eläinainesta tiloilla käytetään hyvăksi. Sianlihantuotannon tehokkuus on Suomessa keskimäärin varsin korkealla tasolla. Re- 
hun hyvăksikăyttő on vain $16 \%$ heikompi ja päivăkasvu $20 \%$ heikompi kuin kantakokeissa. Sikaloiden välinen tulosten variaatio on kuitenkin huomattavan suuri. Keskiarvot parhaimpien ja huonoimpien vălillă poikkeavat $20-30 \%$ toisistaan. Tulokset heikkenevăt ja niiden suhteellinen hajonta suurenee sikalakoon kasvaessa.

Rehun hyväksikäyttő on merkittaavin tuotannon kannattavuuteen vaikuttava tekijä. Rehuhyötysuhteen vaihtelu tiloilla selittää runsaat $30 \%$ lihasian katetuoton vaihtelusta. Sianlihantuotannossa kustannusten vaihtelu on kolmanneksen suurempi kuin tuoton vaihtelu. Rehukustannuksen vaihtelu on kaksinkertainen porsaskustannuksen vaihteluun verrattuna.

Kun elăinaines rajatulla alueella on varsin tasaista johtuu tuotantotulosten vaihtelu sikaloiden sisăisistă tekijoistă. Tiloilla esiintyvă suuri variaatio tuotannon tehokkuudessa ja kannattavuudessa korostaa inhimillisen tekijän, viljelijän henkilökohtaisen panoksen osuutta tuotannon tuloksellisuuden ratkaisijana. 